\title{
Disruption of trophic interactions involving the heather beetle by atmospheric nitrogen deposition ${ }^{\text {म }}$
}

\author{
Angela Taboada $^{\mathrm{a}, \mathrm{b}, *}$, Elena Marcos ${ }^{\mathrm{a}, \mathrm{b}}$, Leonor Calvo ${ }^{\mathrm{a}, \mathrm{b}}$ \\ a Area of Ecology, University of León, E-24071 León, Spain \\ ${ }^{\mathrm{b}}$ Institute of Environmental Research (IMA), University of León, E-24071 León, Spain
}

\section{A R T I C L E I N F O}

Article history:

Received 10 April 2016

Received in revised form 18 June 2016

Accepted 10 July 2016

Available online $\mathrm{xxx}$

Keywords:

Air pollution

Calluna vulgaris heathlands

Herbivory

Lochmaea suturalis

Predation

\section{A B S T R A C T}

Elevated nitrogen $(\mathrm{N})$ deposition impacts the structure and functioning of heathland ecosystems across Europe. Calluna plants under high $\mathrm{N}$-inputs are very sensitive to secondary stress factors, including defoliation attacks by the heather beetle. These attacks result in serious damage or death of Calluna, its rapid replacement by grasses, and the subsequent loss of heathland. We know very little about the mechanisms that control the populations and trigger outbreaks of the heather beetle, impeding proper management measures to mitigate the damage. We investigated the effects of $\mathrm{N}$ deposition on the relationships between the heather beetle, its host plant, and two arthropod predators at building (rejuvenated through fire) and mature heathlands. The study combines field manipulation experiments simulating a range of $\mathrm{N}$ deposition rates $(0$, $1,2,5 \mathrm{~g} \mathrm{~N} \mathrm{~m}^{-2}$ year $^{-1}$ for 2 years, and $5.6 \mathrm{~g} \mathrm{~N} \mathrm{~m}^{-2}$ year $^{-1}$ for 10 years), and food-choice laboratory experiments testing the preferences of adults and larvae of the heather beetle for N-treated Calluna plants, and the preferences of predators for larvae grown on plants with different N-content. The larvae of the heather beetle achieved the highest abundances after the long-term (10-year) addition of $\mathrm{N}$ at mature Calluna plots in the field. Contrary to the adults, the larvae foraged preferentially on the most N-rich Calluna shoots under laboratory conditions. Predators showed no aggregative numerical responses to the accumulation of heather beetle larvae at high $\mathrm{N}$-input experimental plots. During the feeding trials, predators consumed a small number of larvae, both in total and per individual, and systematically avoided eating the larvae reared on high-N Calluna shoots. Our study showed that the most severe defoliation damage by the heather beetle is inflicted at the larval stage under prolonged availability of high- $\mathrm{N}$ inputs, and that arthropod predators might not act as effective regulators of the beetle's populations.

Effects of $\mathrm{N}$ deposition on the heather beetle, its host plant and two predators were investigated by a long-term field manipulation study, laboratory rearing and food-choice experiments.

C) 2016 Published by Elsevier Ltd.

\section{Introduction}

Global rates of atmospheric nitrogen $(\mathrm{N})$ deposition from anthropogenic emissions of total $\mathrm{N}\left(\mathrm{NO}_{\mathrm{y}}\right.$ and $\mathrm{NH}_{\mathrm{x}}$, primarily associated with fossil fuel combustion and food production) are projected to double by 2050 (Galloway et al., 2004), exceeding the critical load thresholds that have detrimental effects on human health and the environment (Dentener et al., 2006; Galloway et al., 2008; Sala et al., 2010). Elevated $\mathrm{N}$ inputs impact both ecosystem composition and functioning, by (1) altering multiple fundamental processes such as decomposition, microbial activity, plant growth and productivity, and species interactions, and by (2) increasing plant susceptibility to secondary stress and disturbance factors (i.e., frost, drought, pathogens, and pests) (Bobbink et al., 2010; Krupa, 2003; Ochoa-Hueso et al., 2011; Throop and Lerdau, 2004). Especially vulnerable to excess N

\footnotetext{
th This paper has been recommended for acceptance by Dr. Hageman Kimberly Jill.

* Corresponding author. Area of Ecology, Department of Biodiversity and Environmental Research, University of León, Campus Vegazana s/n E-24071 León, Spain.

Email address: angela.taboada@unileon.es (A. Taboada)
}

accumulation are $\mathrm{N}$-limited ecosystems adapted to low levels of $\mathrm{N}$ availability (Sala et al., 2010), like semi-natural heathlands dominated by heather, Calluna vulgaris (L.) Hull (hereafter Calluna) (Fagúndez, 2013; Phoenix et al., 2012; Stevens et al., 2016). Both N-manipulation experiments (e.g., Calvo et al., 2005, 2007; Härdtle et al., 2009; Power et al., 2004) and field-scale surveys (e.g., Jones and Power, 2012; Southon et al., 2013) evidenced N-driven changes in the composition, diversity and functioning of heathlands, highlighting atmospheric $\mathrm{N}$ deposition as a major driver of heathland decline across Europe.

Many studies have revealed increases in the annual shoot growth, leaf nutrient content, and flowering of Calluna plants in response to the experimental addition of N (e.g., Friedrich et al., 2011; Power et al., 1998a; Uren et al., 1997; von Oheimb et al., 2010). And yet, few studies have explicitly linked the enriched Calluna nutritional quality induced by $\mathrm{N}$ to its greater sensitivity to biotic stress, particularly to insect attack (Hartley et al., 2003; Kerslake et al., 1998; Power et al., 1998b). Similarly, growing number of researches investigate the response of heathland vegetation to $\mathrm{N}$ deposition in combination with multiple drivers of global change (e.g., land-use change: Härdtle et al., 2009; climate change: Meyer-Grünefeldt et al., 2015), overlooking possible interactions with insect herbivory (see Gladbach, 2010; 
Peñuelas et al., 2004). This is despite defoliation attacks by the main insect herbivore of Calluna, the heather beetle, Lochmaea suturalis (Thomson, 1866) (Coleoptera: Chrysomelidae), being expected to intensify in the next decades in response to higher $\mathrm{N}$ loading and warming (Peñuelas et al., 2004; Phoenix et al., 2012; but see Scherber et al., 2013). Enhanced availability of N very likely improves performance of the heather beetle (e.g., accelerates larval growth, increases body size and survival rate, and augments population numbers) (Berdowski, 1993; Brunsting and Heil, 1985; Power et al., 1998b), and might strengthen the effects of defoliation on the vegetation.

Populations of the heather beetle periodically reach outbreak densities as high as 2000 individuals per square meter (Berdowski, 1993) that result in severe damage or death of Calluna plants, their rapid replacement by grasses, and the subsequent loss of heathland (Berdowski and Zeilinga, 1987; Bobbink and Heil, 1993; Brunsting and Heil, 1985; but see Scandrett and Gimingham, 1991). Based on past defoliation episodes, numerous variables have been suggested to influence the magnitude (i.e., incidence, extent, and intensity) of a heather beetle outbreak (e.g., nitrogen and sulphur deposition: Berdowski, 1993; temperature: Staley, 2000; precipitation: Berdowski, 1993; von Melber and Heimbach, 1984), but proper experimental work is needed to support these claims. Also, the extent to what Calluna plants of different ages (i.e., growth phases; Gimingham, 1972) are more or less susceptible and resilient to heather beetle attacks remains untested. So far, our knowledge on the ecology of the heather beetle and the factors that trigger and end an outbreak is scarce (Pinder et al., 2015a), and, as a consequence, current management advice to mitigate the damage is conflicting and insufficient (Pinder et al., 2015b; Rosenburgh and Marrs, 2010). Moreover, the latest systematic review by Pinder et al. (2015a) established that we know very little about the relationships between the heather beetle and its natural enemies (predators, parasites, and pathogens), and whether these might act as effective population regulators (Scandrett and Gimingham, 1991). Up to now, no specialist predators of the heather beetle have been documented in the field, and only a few generalist arthropod predators (e.g., ladybird beetles, ground beetles, and true bugs) have been mentioned in the literature as potential control agents of the beetle's populations (Cameron et al., 1944).

This study offers new insights into the relationships between the heather beetle, its host plant and two generalist arthropod predators (ground beetles and harvestmen) that are highly abundant in Calluna heathlands (Cuesta, 2015), mediated by $\mathrm{N}$ deposition and the age of heathland vegetation (see Jones and Power, 2015). Specifically, we aim to investigate: (i) whether the heather beetle displays behavioural adaptations to locate and forage preferentially on the most $\mathrm{N}$-rich plant tissues, as a response to low natural availability of $\mathrm{N}$ (Chen et al., 2010; Fernandez and Hilker, 2007; Ikonen, 2002); (ii) whether predators can feed preferentially on preys of high nutritional quality raised on $\mathrm{N}$-enriched plants to regulate their intake of nutrients and compensate the limited availability of $\mathrm{N}$ in the ecosystem (Mayntz and Toft, 2001; Mayntz et al., 2005); (iii) whether predators show aggregative numerical responses to high prey accumulation triggered by plant $\mathrm{N}$-enrichment, maximizing their efficiency as natural enemies (Monsrud and Toft, 1999); and (iv) whether the abundances of the heather beetle and its predators are likewise impacted by different rates of $\mathrm{N}$ loading (Haddad et al., 2000) and by $\mathrm{N}$-driven changes in heathland vegetation at different growth phases of Calluna development.

\section{Material and methods}

\subsection{Study area and experimental design}

The study was performed in three Calluna heathland sites located in the Cantabrian Mountains (NW Spain; 430- $03^{\prime} \mathrm{N}, 5^{\circ} 21-26^{\prime} \mathrm{W}$; 1560-1660 $\mathrm{m}$ a.s.1.; 18-35 ha), and subjected to minimal regular free-range grazing by cattle and horses (1-2 $\mathrm{LU} \mathrm{ha}^{-1}$ year $\left.^{-1}\right)$ in June-September. Estimations of current total atmospheric N deposition in the study area $\left(7.5-15 \mathrm{~kg} \mathrm{~N} \mathrm{ha}^{-1}\right.$ year $^{-1}$; García-Gómez et al., 2014) are close to exceed the critical load that threatens the persistence of European dry Calluna heathlands (i.e., $10-20 \mathrm{~kg} \mathrm{~N} \mathrm{ha}^{-1}$ year $^{-1}$; Bobbink et al., 2010). In each site, we selected two differently-aged heathland areas: (1) rejuvenated through prescribed fire in 2005, and (2) mature showing first signs of degeneration after 30-40 years of land use abandonment (i.e., building- and mature-phase; Gimingham, 1972). We randomly established a total of $902 \times 2 \mathrm{~m}$ plots and performed a manipulative experiment to modify plant $\mathrm{N}$ availability, consisting of five different $\mathrm{N}$-addition treatments (i.e., 3 plots per treatment, age class, and site): $0 \mathrm{~g} \mathrm{~m}^{-2}$ year $^{-1}$ (control, hereafter ' $\mathrm{N} 0$ '), $1 \mathrm{~g} \mathrm{~m}^{-2}$ year $^{-1}$ ('N1'), $2 \mathrm{~g} \mathrm{~m}^{-2}$ year $^{-1}$ ('N2'), and $5 \mathrm{~g} \mathrm{~m}^{-2}$ year $^{-1}$ ('N5') of granules of ammonium nitrate monthly added in June-November from 2013 to 2014 ; and $5.6 \mathrm{~g} \mathrm{~m}^{-2}$ year $^{-1}$ ('N5.6') monthly added in May-October from 2005 to 2014 (see Cuesta et al., 2008), equivalent to the predicted $\mathrm{N}$ input by 2050 (Galloway et al., 2004).

\subsection{Food-choice laboratory experiments}

To test whether the heather beetle might preferentially forage on Calluna plants grown under certain N-input conditions, we conducted two series of $96 \mathrm{~h}$ food-choice ("cafeteria") experiments (July-August 2014): (1) newly molted third-instar larvae and (2) adults were allowed to choose between pairs of current-year apical shoots obtained from the field experimental plots: 10 pair combinations (N0 vs. N1, N2, N5, N5.6; N1 vs. N2, N5, N5.6; N2 vs. N5, N5.6; and N5 vs. $\mathrm{N} 5.6) \times 3$ replicates $\mathrm{x} 3$ larvae (i.e., 90 larvae in total), and 4 pair combinations (N0 vs. N1, N2, N5, N5.6) x 3 replicates x 3 adults (i.e., 36 adults in total). First- and second-instar larvae were collected outside the experimental plots in the three study sites by vegetation beating while holding a $23 \times 35 \mathrm{~cm}$ tray underneath, reared in pint-sized BugDorm plastic containers ( $720 \mathrm{ml}$; BugDorm Store, Megaview Inc., Taiwan) at $20-25^{\circ} \mathrm{C}$ and 15:9 h L:D regime in the laboratory, and fed on control Calluna shoots until they reached early third-instar larval or adult stages for the cafeteria experiments. As the number of third-instar larvae grown under laboratory conditions tripled the adults, higher number of feeding pair combinations were feasible for the larvae. The experiments were set up in BugDorm containers with moist filter paper to prevent desiccation. All the apical shoots used in the experiments were as similar as possible in weight $(0.52 \pm 0.20 \mathrm{~g})$ and morphological characteristics (e.g., number of twigs and amount of leaves). For each apical shoot we assessed defoliation by calculating shoot weight loss as the difference between the initial and final shoot weight during the cafeteria experiments, after correcting for natural weight loss $(36.2 \%)$ due to shoot dehydration in the same laboratory conditions.

The preferences of ground beetles (Coleoptera: Carabidae) for third-instar heather beetle larvae reared on Calluna shoots grown under different $\mathrm{N}$-input conditions were investigated by a $15 \mathrm{~h}$ cafeteria experiment (August 2014) using adults of Calathus asturiensis Vuillefroy, 1866, the most abundant generalist ground beetle predator in the 
study sites (Cuesta et al., 2006) as the test species. First- and second-instar larvae were collected by vegetation beating in the study sites, and reared in BugDorm containers in the laboratory on Calluna shoots harvested from the experimental plots with different $\mathrm{N}$-addition treatments (N0, N1, N2, N5, and N5.6) till they reached the third instar. The larvae were then stored frozen until used in the cafeteria experiment. Predators were captured by live pitfall trapping [50 plastic dry pitfall traps consisting of a large cup ( $85 \mathrm{~mm}$ diameter, $100 \mathrm{~mm}$ high) containing an inverted medium-sized cup (62 $\mathrm{mm}$ diameter, $88 \mathrm{~mm}$ high); see Taboada et al., 2012 for details] outside the experimental plots in the three heathland sites in July-August 2014, and kept in the laboratory on a diet of second-, third-instar larvae and pupae of the heather beetle until the experiment. Predators were deprived of food for $48 \mathrm{~h}$ before the experiment and randomly assigned to the feeding trials. The experiment was set up in 20 Petri dishes (14 cm diameter) with moist filter paper, and consisted of 5 replicates in which an individual predator (20 adults in total) could choose between paired combinations of larvae (i.e., two groups of 6 larvae; 240 larvae in total): N0 vs. N1, N2, N5, and N5.6. Paired groups of larvae were labelled and offered simultaneously to emulate the natural scenario of a wandering generalist predator that actively searches for and selects between different available preys (Mayntz et al., 2005). The experiment was conducted at $20-22^{\circ} \mathrm{C}$, between 8 p.m. and 11 a.m., under natural illumination strengthened by a red light lamp to allow observation of predator activity. We recorded the order in which predators consumed the larvae of the heather beetle and the total number of larvae consumed per $\mathrm{N}$ treatment in each replicate.

\subsection{Enclosure field experiment}

We used an enclosure field experiment to study the aggregative numerical responses of predatory ground beetles in the study sites to different densities of the larvae of the heather beetle related to the $\mathrm{N}$-addition treatments (N0, N1, N2, N5, and N5.6). The experiment was conducted in the rejuvenated heathland plots as Calluna plants at the building phase reach their greatest production of new shoots per unit area (Gimingham, 1972; Jones and Power, 2015). According to Scandrett and Gimingham (1991), lateral migration of the larvae in the Calluna canopy is minimal and only occurs when food is limiting. Each $2 \times 2 \mathrm{~m}$ plot (i.e., 45 plots in total) was fenced with a $30 \mathrm{~cm}$-high polypropylene mesh $\left(105 \mathrm{~g} / \mathrm{m}^{2}\right)$ fixed to the ground with metal sticks to effectively retain the larvae within the enclosure. Larval density in the enclosed plots was estimated by vegetation beating during their peak activity period (sampling effort: 2 persons x $15 \mathrm{~min}$ per plot; 24-25 July 2014), after which all the larvae captured were counted and set free at their original plots.

One live pitfall trap per enclosed plot was used to collect predatory ground beetles in four occasions (29 July-12 August 2014), and the beetles trapped were immediately released outside the plots to grant predator unbounded aggregative behaviour. Pitfall catches reflect arthropod activity-density that will be referred to here as abundance or number of individuals. Ground beetles were identified to the species level using standard keys (Jeannel, 1941-1942; Lindroth, 1974) and follow the nomenclature in Serrano (2003). Additionally, the ability of ground beetles to move unconstrained through the enclosures was evaluated by a mark-release-recapture experiment. A total of 75 individuals (48 males and 27 females) of the test species $C$. asturiensis were trapped outside the experimental plots in the three heathland sites, marked individually with unique number-coded combinations of dots in the elytra using a small drill, and kept in the laboratory on a diet of second-, third-instar larvae and pupae of the heather beetle until the experiment. Marked individuals were released at different densities $(0,1$, and 4 individuals per plot) into the enclosures with the pitfall traps closed to allow a 5-day settling in period (24-28 July 2014). At each site, the three plots per N-treatment (N0, $\mathrm{N} 1, \mathrm{~N} 2, \mathrm{~N} 5$, and N5.6) were randomly assigned to one of the three predator densities (i.e., 15 plots per density in total).

\subsection{Observational field study}

We investigated the responses of the larvae of the heather beetle and its two main generalist arthropod predators in the study sites, i.e., ground beetles and harvestmen (Arachnida: Opiliones), to the different $\mathrm{N}$-addition treatments and the age of heather plants. We sampled the larvae and the two predator groups by pitfall trapping at the experimental plots [one plastic cup $(85 \mathrm{~mm}$ diameter, $100 \mathrm{~mm}$ high) partly filled with $25 \%$ propylene glycol per plot], after removal of the enclosures and during the peak activity period of the larvae (15-31 August 2014). Pitfall trapping has been shown as an effective method to sample the larvae of the heather beetle in prior comparative studies (Cuesta, 2015; see also Cuesta et al., 2008). The larvae are found on the ground or just beneath the surface (1) at the time of egg hatching and before climbing into the vegetation, (2) when accidentally fallen from the vegetation, (3) after dropping to the ground as a behavioural response to disturbance, (4) when reaching the pre-pupal stage and descending to the ground to pupate, and (5) possibly when seeking protection from adverse weather conditions (Pinder et al., 2015a; Rosenburgh and Marrs, 2010; Scandrett and Gimingham, 1991). Ground beetles and harvestmen were identified to the species level using standard keys (Hillyard and Sankey, 1989; Jeannel, 1941-1942; Lindroth, 1974; Sánchez-Cuenca, 2012) and follow the nomenclature in Serrano (2003) and Prieto (2003, 2008), respectively.

In addition, we measured three sets of environmental variables (17 variables in total) to evaluate their relevance as abiotic predictors of the abundance of the larvae and the two predator groups in the experimental plots (Table 1).

\subsection{Data analysis}

We analysed separately the preference of third-instar larvae and adults of the heather beetle in the cafeteria experiments by fitting two linear models (LMs) with shoot weight loss as the response variable and $\mathrm{N}$-addition treatment (N0, N1, N2, N5, and N5.6) as the predictor variable. We modelled shoot weight loss data following a Gaussian error distribution, using the identity link function.

We tested the response of predatory ground beetles to the density of heather beetle larvae in the experimental plots by performing a generalised linear mixed model (GLMM) with the number of predator individuals as the response variable, $\mathrm{N}$-addition treatment (N0, N1, N2, $\mathrm{N} 5$, and N5.6) and the number of larval individuals as fixed factors, and the identity of the heathland sites as random factor. We modelled predator data following a negative binomial error distribution, using the log link function, and obtained predicted values of the number of predator individuals for each $\mathrm{N}$ treatment and heathland site, based on the mean values $(N=15)$ of larval density for each site.

We fitted generalised linear models (GLMs) to assess the response of the heather beetle and its main predators to the different $\mathrm{N}$ treatments and the age of heather plants. The pitfall catches of each site (i.e., 3 plots per $\mathrm{N}$ treatment and age) and for the whole trapping period were pooled. The response variables in the models were total number of larvae of the heather beetle, total number of individuals of predatory ground beetles and harvestmen. Abundance data were modelled following a negative binomial error distribution, using the $\log$ link function. The predictor variables were the age of heather plants

(reju- 
Table 1

Abiotic predictor variables grouped in three categories (NUTRIENT, GROWTH, and HABITAT) and measured at the experimental plots.

\begin{tabular}{|c|c|c|c|c|}
\hline Category & $\begin{array}{l}\text { Year of } \\
\text { measurement }\end{array}$ & Abbreviation & Description & Unit \\
\hline $\begin{array}{l}\text { Nutrient content } \\
\text { (NUTRIENT) }\end{array}$ & 2013,2014 & N_2013, N_2014 & $\begin{array}{l}\text { Nitrogen }(\mathrm{N}) \\
\text { content of } 5 \\
\text { randomly- } \\
\text { selected apical } \\
\text { shoots of Calluna } \\
\text { vulgaris per plot }\end{array}$ & $\%$ \\
\hline \multirow[t]{2}{*}{$\begin{array}{l}\text { Annual growth } \\
\text { (GROWTH) }\end{array}$} & 2013, 2014 & $\begin{array}{l}\text { SHOOT_2013, } \\
\text { SHOOT_2014 }\end{array}$ & $\begin{array}{l}\text { Mean length value } \\
\text { of } 5 \text { randomly- } \\
\text { selected apical } \\
\text { shoots of Calluna } \\
\text { vulgaris per plot }\end{array}$ & $\mathrm{cm}$ \\
\hline & & $\begin{array}{l}\text { FLOWERS_2013, } \\
\text { FLOWERS_2014 }\end{array}$ & $\begin{array}{l}\text { Mean number of } \\
\text { flowers of } 5 \\
\text { randomly- } \\
\text { selected apical } \\
\text { shoots of Calluna } \\
\text { vulgaris per plot }\end{array}$ & \\
\hline \multirow{11}{*}{$\begin{array}{l}\text { Habitat structure } \\
\text { (HABITAT) }\end{array}$} & 2014 & BARESOIL & Bare soil cover & $\%$ \\
\hline & & SHRUBS & $\begin{array}{l}\text { Total shrub } \\
\text { species cover }\end{array}$ & $\%$ \\
\hline & & CALLUNA & $\begin{array}{l}\text { Calluna vulgaris } \\
\text { cover }\end{array}$ & $\%$ \\
\hline & & E_AUSTRALIS & $\begin{array}{l}\text { Erica australis } \\
\text { cover }\end{array}$ & $\%$ \\
\hline & & E_TETRALIX & $\begin{array}{l}\text { Erica tetralix } \\
\text { cover }\end{array}$ & $\%$ \\
\hline & & VACCINIUM & $\begin{array}{l}\text { Vaccinium } \\
\text { myrtillus cover }\end{array}$ & $\%$ \\
\hline & & HERBS & $\begin{array}{l}\text { Total herb species } \\
\text { cover }\end{array}$ & $\%$ \\
\hline & & MOSSES & Moss cover & $\%$ \\
\hline & & LICHENS & Lichen cover & $\%$ \\
\hline & & CETRARIA & $\begin{array}{l}\text { Cetraria islandica } \\
\text { cover }\end{array}$ & $\%$ \\
\hline & & CLADONIA & $\begin{array}{l}\text { Cladonia spp. } \\
\text { cover }\end{array}$ & $\%$ \\
\hline
\end{tabular}

venated, mature), N-addition treatment (N0, N1, N2, N5, and N5.6) and their interaction. The interaction term was retained in the models only when significant.

Besides, we investigated the importance of the environmental variables measured at the experimental plots as predictors of the abundance of the heather beetle larvae, ground beetles and harvestmen, by fitting GLMs with the number of individuals of each arthropod group as the response variables. Abundance data were modelled following a negative binomial error distribution, using the log link function. The starting sets of predictors consisted of environmental variables that resulted in univariate GLMs with $p<0.1$ and with the highest explained deviance. To avoid collinearity, only uncorrelated variables (Spearman's rank correlation coefficient $-0.7<\rho<0.7$ ) were considered in the models. Collinearity was further assessed by examining the variance inflation factor (VIF) of the predictors. We sequentially dropped the covariate with the highest VIF from the models, until all predictor VIFs were smaller than the preselected threshold value of 5 . In addition, the abundance of the larvae of the heather beetle was in- cluded as predictor variable in the ground beetle and harvestman models. Minimal adequate models (MAMs) to describe the data were determined by both backward and forward stepwise variable selection based on Akaike's information criterion (AIC). We measured the goodness of fit of the MAMs to the data by Nagelkerke's coefficient of determination $\left(R^{2}\right)$. We initially performed GLMMs for the three arthropod groups, considering the identity of the heathland sites as random factor. However, the relevance of the random factor in the models was always negligible (i.e., standard deviation values $<0.00001$ ), and the increase in model complexity did not improve predictive power and, therefore, only GLMs are reported.

All data analyses were carried out with R software, version 3.1.2 (R Core Team, 2014), using the 'MASS' (Venables and Ripley, 2002), 'nlme' (Pinheiro et al., 2014), 'car' (Fox and Weisberg, 2011) and 'fmsb' (Nakazawa, 2014) packages.

\section{Results}

\subsection{Food-choice laboratory experiments}

The loss of Calluna shoot weight after defoliation by third-instar larvae of the heather beetle was significantly higher $(\mathrm{F}=6.05$, $p<0.001)$ for the apical shoots harvested from the experimental plots with the highest N-input treatments (N2, N5, and N5.6; Fig. 1); and especially for shoots gathered from heather plants subjected to long-term (10 years) $\mathrm{N}$-addition (N5.6). No significant differences $(\mathrm{F}=1.21$, $p=0.341$ ) were, however, found in shoot weight loss following defoliation by adults of the heather beetle. Average shoot weight loss caused by defoliation was lower for third-instar larvae $(0.018 \mathrm{~g} / \mathrm{indi}-$ vidual) than for the adults $(0.032 \mathrm{~g} /$ individual $)$.

The total number of larvae of the heather beetle eaten by the test species $C$. asturiensis in the 20 trials of the cafeteria experiment was low (i.e., 56 larvae eaten of 240 larvae in total); and the majority (73\%) of them had been reared on Calluna shoots picked from N0 plots. In half of the trials, both the larvae eaten in first place and the highest number of consumed larvae per trial belonged to the group that had been reared on shoots from N0 plots. Each predator individual consumed an average of 2.8 larvae of the heather beetle per trial.

\subsection{Enclosure field experiment}

We sampled 416 larvae of the heather beetle by vegetation beating, and 68 individuals of predatory ground beetles ( 60 unmarked individuals of C. asturiensis, 3 individuals of Cryobius cantabricus, 2 Nebria asturiensis, 2 Carabus macrocephalus, and 1 Carabus amplipennis) by live pitfall trapping in the enclosed experimental plots. We found no significant aggregative response of ground beetles to the number of larvae thriving in each plot (Tables 2 and 3). However, more than $40 \%$ of the overall variance in the ground beetle data set was explained by the identity of the heathland sites.

We confirmed the ability of ground beetles to move freely through enclosures since only 7 of 75 marked individuals of the test species $C$. asturiensis liberated into the fenced plots were recaptured, nearly all of them (6 individuals) in plots different from and submitted to lower $\mathrm{N}$-input treatments than the ones where originally released.

\subsection{Observational field study}

We captured 183 larvae of the heather beetle, 331 individuals and 15 species of predatory ground beetles (mainly C. asturiensis, $C$. amplipennis, $N$. asturiensis, C. cantabricus, and C. macrocephalus), and 351 individuals and 3 species of harvestmen (Phalangium opilio, Odiellus simplicipes, and $O$. seoanei). Both the larvae and ground bee- 
Heather beetle larva

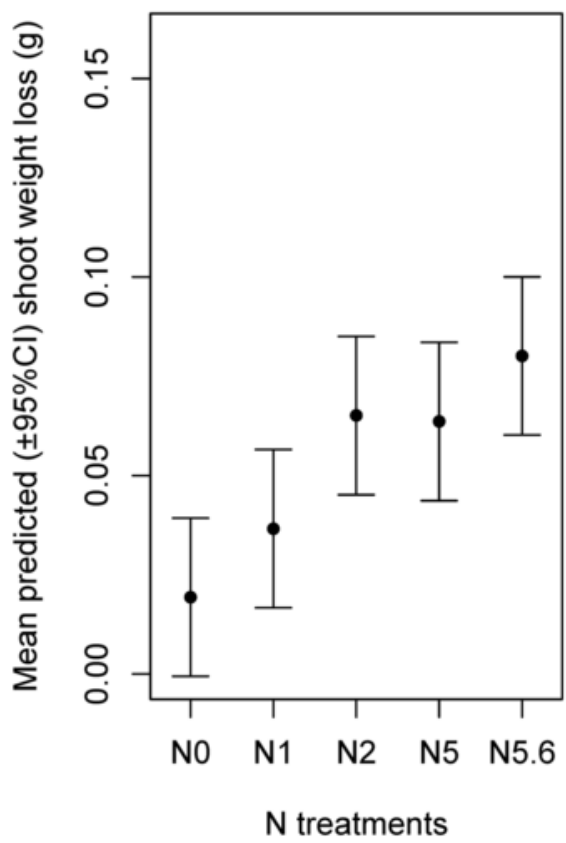

Heather beetle adult

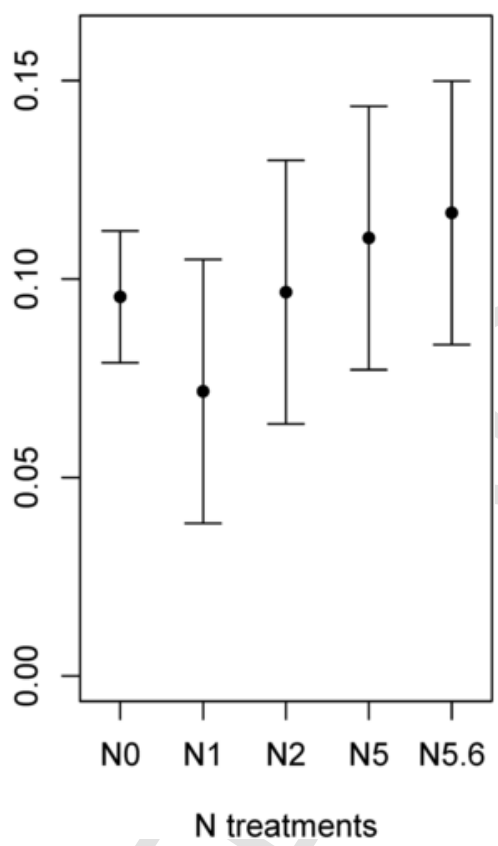

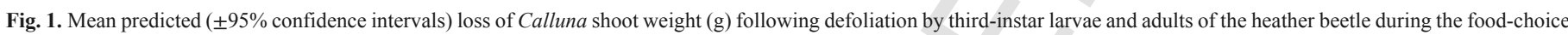
("cafeteria") experiments.

Table 2

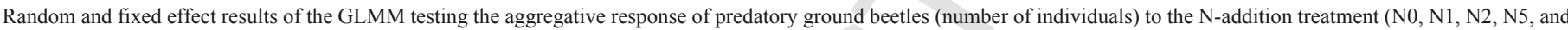

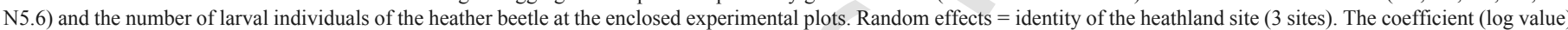

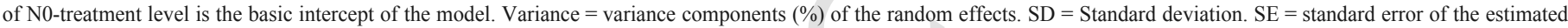
coefficient. Degrees of freedom $=45$.

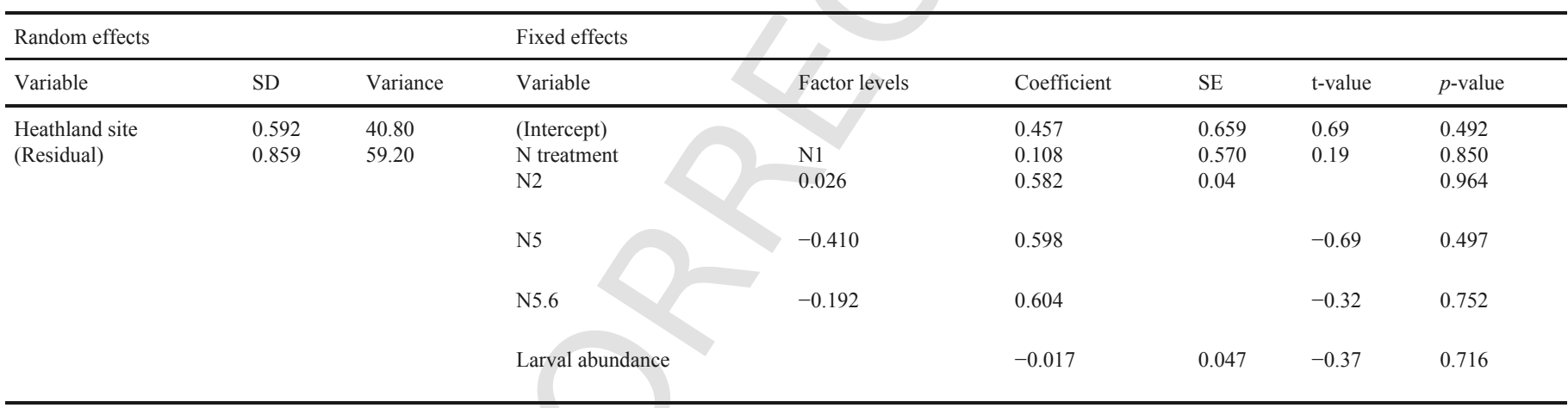

Table 3

Mean $( \pm \mathrm{SE})$ number of larval individuals of the heather beetle $(N=9)$ and mean $( \pm \mathrm{SE})$ predicted number of ground beetles at the enclosed experimental plots with different $\mathrm{N}$-addition treatments. Predicted values were calculated by averaging the GLMM predictions individually obtained for the three heathland sites (see text for further details).

\begin{tabular}{|c|c|c|c|c|c|}
\hline & \multicolumn{5}{|l|}{$\mathrm{N}$ treatment } \\
\hline & N0 & N1 & N2 & N5 & N5.6 \\
\hline $\begin{array}{c}\text { Heather } \\
\text { beetle } \\
\text { larvae }\end{array}$ & $7.67 \pm 1.94$ & $9.67 \pm 1.51$ & $10.56 \pm 1.52$ & $6.78 \pm 1.38$ & $11.56 \pm 1.72$ \\
\hline $\begin{array}{r}\text { Ground } \\
\text { beetles }\end{array}$ & $1.59 \pm 0.68$ & $1.77 \pm 0.75$ & $1.63 \pm 0.69$ & $1.05 \pm 0.45$ & $1.31 \pm 0.56$ \\
\hline
\end{tabular}

tles responded significantly to the age of heather plants and to the $\mathrm{N}$ treatments, whereas no significant response was observed for harvestmen (Table 4, Fig. 2). Higher number of larvae was collected in plots where $\mathrm{N}$ was added for 10 years (N5.6), particularly in the mature phase of heather development. No consistent trend in the abundance of ground beetles was observed, since more individuals were collected from both N0 plots in the rejuvenated heathland areas and N5.6 plots in the mature ones.

The larvae of the heather beetle were mostly influenced by environmental variables related to their host-plant, especially N_2013 (Table 5). The highest larval abundance was recorded from N5.6 plots where Calluna plants exhibited the greatest values of both N_2013 and SHOOT 2013 (Fig. 3). Ground beetles and harvestmen were mostly influenced by the characteristics of the habitat where typi- 
Table 4

GLM results for the observational field study. The response variables in the models are the abundance (number of individuals) of the heather beetle larvae, predatory ground beetles and harvestmen. The predictor variables are the age of heather plants (rejuvenated, mature), the $\mathrm{N}$-addition treatment (N0, N1, N2, N5, and N5.6) and their interaction (retained in the models only when significant). Resid.DF $=$ residual degrees of freedom. Resid.Deviance $=$ residual deviance is the amount of variation not explained by the predictors. $P$-values smaller than $0.05\left(\chi^{2}\right.$ distribution $)$ are in bold face.

\begin{tabular}{|c|c|c|c|c|c|}
\hline $\begin{array}{l}\text { Response } \\
\text { variable }\end{array}$ & $\begin{array}{l}\text { Predictor } \\
\text { variable }\end{array}$ & Deviance & Resid.Df & Resid.Deviance & $p$-value \\
\hline \multirow{3}{*}{$\begin{array}{l}\text { Heather beetle } \\
\text { abundance }\end{array}$} & Null & & 29 & 83.42 & \\
\hline & Heather age & 10.26 & 28 & 73.16 & 0.001 \\
\hline & $\mathrm{N}$ treatment & 41.29 & 24 & 31.87 & $<0.001$ \\
\hline \multirow{4}{*}{$\begin{array}{l}\text { Ground beetle } \\
\text { abundance }\end{array}$} & Null & & 29 & 71.36 & \\
\hline & Heather age & 11.80 & 28 & 59.56 & $<0.001$ \\
\hline & $\mathrm{N}$ treatment & 13.59 & 24 & 45.98 & 0.009 \\
\hline & $\begin{array}{l}\text { Heather age: } \mathrm{N} \\
\text { treatment }\end{array}$ & 15.82 & 20 & 30.16 & 0.003 \\
\hline \multirow{3}{*}{$\begin{array}{c}\text { Harvestman } \\
\text { abundance }\end{array}$} & Null & & 29 & 32.75 & \\
\hline & Heather age & 1.07 & 28 & 31.68 & 0.301 \\
\hline & $\mathrm{N}$ treatment & 1.71 & 24 & 29.97 & 0.788 \\
\hline
\end{tabular}

cally dwell in (i.e., ground surface and shrub layer, respectively) (Table 5).

\section{Discussion}

It is generally assumed that both larvae and adults of the heather beetle consume the tips, leaves and bark of the apical shoots of $\mathrm{Cal}$ luna at all phases of plant development (sensu Gimingham, 1972), but only the larvae are responsible for the characteristic brown or red colouration of the injured plants (Cameron et al., 1944). Even if the factors determining the severity of the beetle's attacks are still unidentified (Pinder et al., 2015a; Rosenburgh and Marrs, 2010), the damage inflicted to the vegetation is expected to intensify with increasing exposure of the Calluna plants to nutrient deposition, mainly to airborne N pollutants (reviewed in Berdowski, 1993; Pinder et al., 2015a). However, neither the attractiveness of Calluna plants with different $\mathrm{N}$ content nor the many aspects of host-plant search and acceptance by the heather beetle (see Fernandez and Hilker, 2007) have been investigated to date. Opposite to the results obtained for the adults of several chrysomelid species (Ikonen, 2002), the adults of the heather beetle did not display behavioural adaptations to locate and utilise the most N-rich plant tissues in our laboratory experiments, at least from the time of emergence following pupation, until the start of hibernation when feeding ceases. These newly emerged adults exhibited instead high rates of food consumption per individual most likely to compensate for low plant nutrient content (see review by Behmer, 2009), attain optimal body weight before hibernation, and thereafter reduce overwintering mortality (Berdowski, 1993; Brunsting, 1982; Brunsting and Heil, 1985; Cameron et al., 1944). Likewise, it seems reasonable to assume that once the adults will exit from hibernation they may still be unable to identify the Calluna shoots with highest $\mathrm{N}$ concentration, while they will continue to ingest high quantities of lower N-content food to complete flight muscle development for dispersal and produce eggs for reproduction (see Brunsting, 1982). These premises, together with the fact that flying adults are unintentionally carried away by the wind (Cameron et al., 1944), make us believe that large adult densities occur in high $\mathrm{N}$-input heathland areas in spring, not as the result of a massive arrival of individuals seeking for host plants with high nutritional quality, but as the consequence of a better survival rate at the preceding larval stage and through the hibernation period induced by high leaf $\mathrm{N}$ content the previous year (see Brunsting and Heil, 1985; Power et al., 1998b).

On the other hand, the larvae of the heather beetle were able to detect and feed preferentially on the most N-rich Calluna shoots under controlled laboratory conditions. Since growth of the heather beetle occurs almost exclusively at this life stage (Brunsting, 1982), the larvae are expected to be more pronouncedly affected by the availability and nutritional status of Calluna plants (Throop and Lerdau, 2004), and, possibly, by an increase in airborne $\mathrm{N}$ supply in the heathland ecosystem. Many field-scale surveys and manipulation experiments
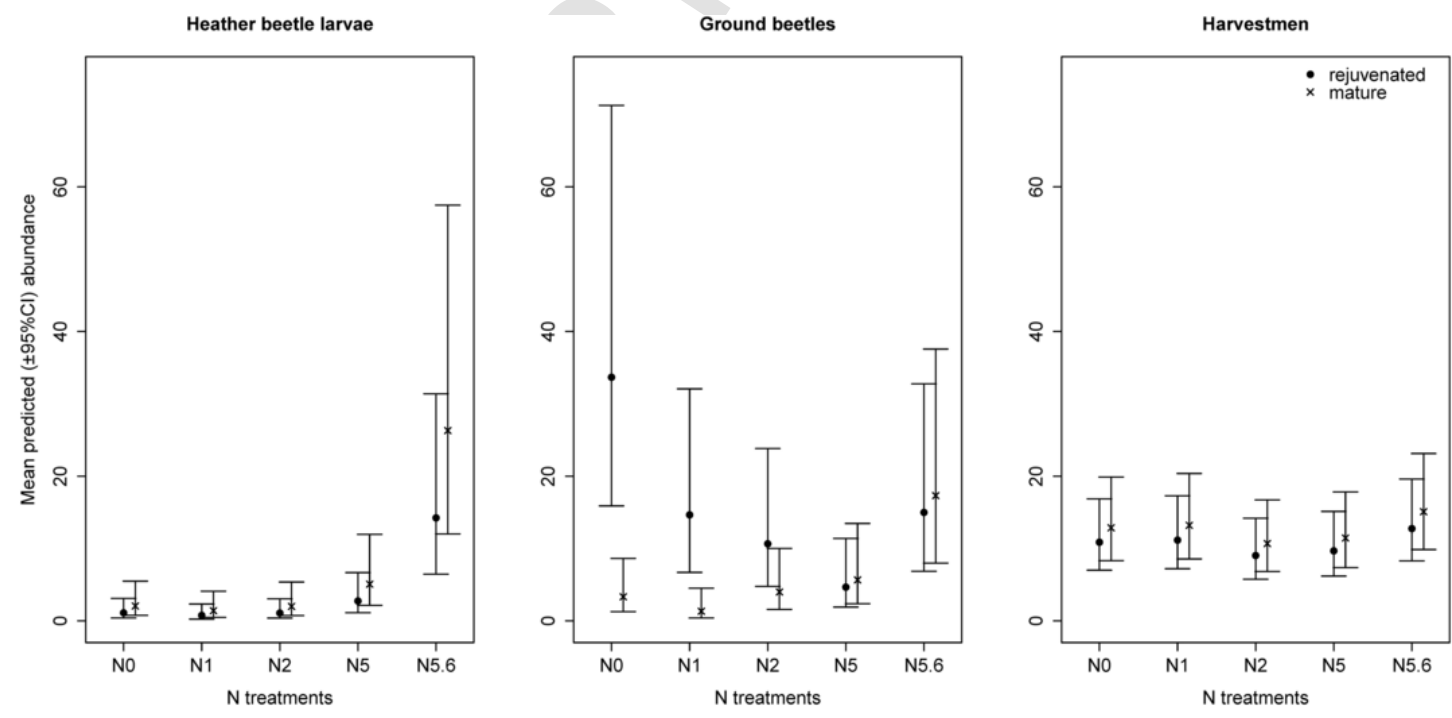

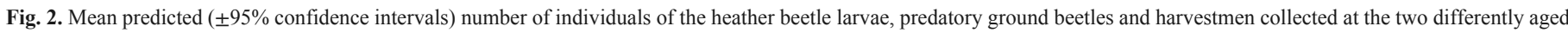
heathland areas (rejuvenated, mature) and the five $\mathrm{N}$-addition treatment plots during the observational field study. 
Table 5

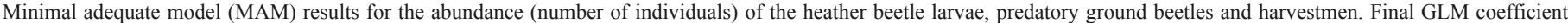

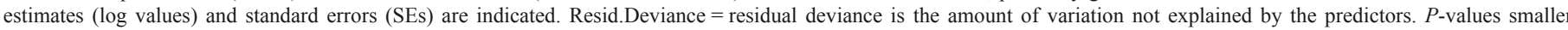

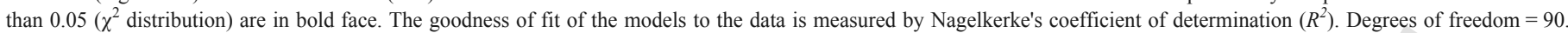
LARVA $=$ abundance of the larvae of the heather beetle. For predictor abbreviations see Table 1.

\begin{tabular}{|c|c|c|c|c|c|c|c|}
\hline & & & & & Coefficie & & \\
\hline Response variable & Null deviance & Predictor variable & Resid.Deviance & $p$-value & Estimate & $\mathrm{SE}$ & $R^{2}$ \\
\hline \multirow[t]{4}{*}{ Heather beetle abundance } & \multirow[t]{4}{*}{195.90} & (Intercept) & & & -8.354 & 1.239 & \multirow[t]{4}{*}{0.82} \\
\hline & & N_2013 & 95.85 & $<0.001$ & 4.781 & 0.643 & \\
\hline & & SHOOT_2013 & 92.81 & 0.082 & -0.253 & 0.133 & \\
\hline & & CALLUNA & 79.83 & $<0.001$ & 0.048 & 0.013 & \\
\hline \multirow[t]{3}{*}{ Ground beetle abundance } & \multirow[t]{3}{*}{123.14} & (Intercept) & & & 2.093 & 0.309 & \multirow[t]{3}{*}{0.33} \\
\hline & & CLADONIA & 101.12 & $<0.001$ & -0.093 & 0.024 & \\
\hline & & BARESOIL & 98.07 & 0.081 & -0.016 & 0.009 & \\
\hline \multirow[t]{4}{*}{ Harvestman abundance } & \multirow[t]{4}{*}{123.65} & (Intercept) & & & 0.961 & 0.116 & \multirow[t]{4}{*}{0.29} \\
\hline & & E_TETRALIX & 116.48 & 0.007 & 0.015 & 0.005 & \\
\hline & & VACCINIUM & 104.32 & $<0.001$ & 0.017 & 0.005 & \\
\hline & & LARVA & 101.83 & 0.114 & 0.023 & 0.014 & \\
\hline
\end{tabular}
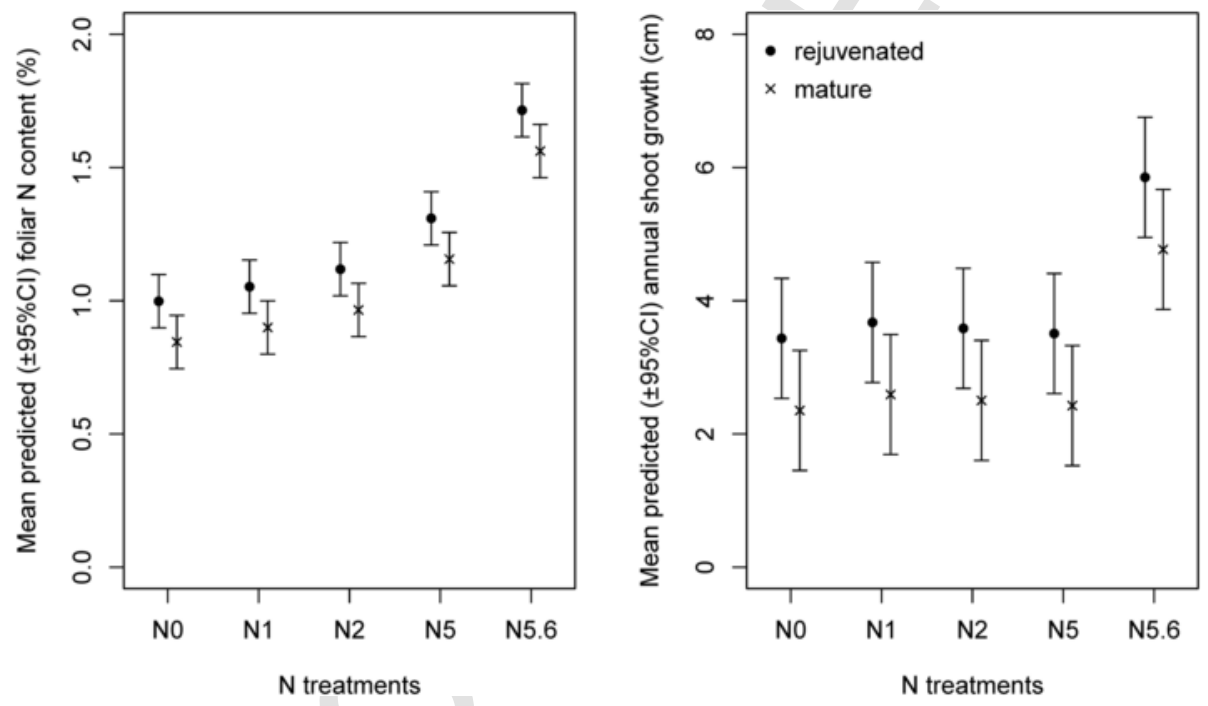

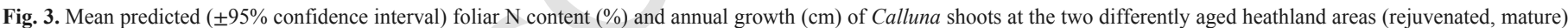

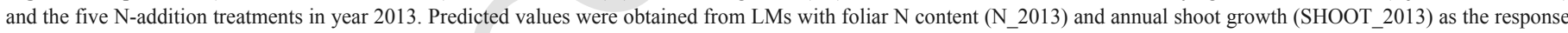

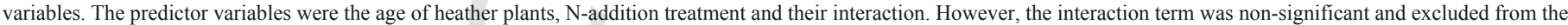
models. See Table 1 for further details.

over different time scales have linked these $\mathrm{N}$ inputs to increases in Calluna annual shoot growth and total plant biomass (e.g., Power et al., 1998a; Uren et al., 1997), and foliar nutrient content (e.g., Jones and Power, 2015; Pitcairn and Fowler, 1995; Power et al., 1998b), i.e., to increases in the quantity and quality of food for the larvae. Indeed, a small number of short-term field and laboratory experiments that reared heather beetle larvae on $\mathrm{N}$-enriched Calluna shoots revealed marked improvements in larval individual performance (i.e., developmental speed, body size, and survival rate) and subsequent adult weight, primarily associated to the increase in leaf tissue $\mathrm{N}$ concentra- tion (Berdowski, 1993; Brunsting and Heil, 1985; Power et al., 1998b).

Similar improvements in growth, survival and development are thus very likely to occur in real-world heathland ecosystems as a result of the enhanced availability of $\mathrm{N}$ due to pollution, and to successively translate into bigger population numbers and a considerably higher risk of population outbreaks of the heather beetle (Brunsting and Heil, 1985; Cuesta et al., 2008; Power et al., 1998b; see also Chen et al., 2010; Throop and Lerdau, 2004). In our field fertilisation experiment, the larvae of the heather beetle achieved high population numbers after the long-term (10-year) addition of $\mathrm{N}$, especially at the ma- 
ture phase of heather development. These findings indicate that the impacts of elevated $\mathrm{N}$ deposition on the larvae are exacerbated over time, in line with prior manipulative experiments reporting that prolonged $\mathrm{N}$ loading results in large, persistent effects on the functioning of heathlands (e.g., soil biochemistry, Calluna growth, phenology, stress sensitivity, and nutrient composition: Phoenix et al., 2012; Southon et al., 2012). This great larval abundance was mainly explained by the high foliar $\mathrm{N}$ content of Calluna plants reported in the preceding year. Earlier larval and adult foraging on N-enriched $\mathrm{Cal}$ luna tissues may have led to an increase in the number of larvae of the new generation (see Brunsting and Heil, 1985; Power et al., 1998b), owing to a series of potential N-derived benefits to the preceding generation that remain to be confirmed: (a) faster larval growth, shortening the duration of the larval stage, (b) increased larval body size, especially at the third instar of development, (c) increased adult body size and condition (e.g., energy reserves and flight muscle development) following pupation, (d) reduced individual mortality during larval molting, through pupation and adult hibernation in the litter layer, and during adult dispersal flights before the reproductive period, (e) rapid sexual maturation of overwintered adults, and (f) enhanced adult fecundity due to either better fitted females producing greater number of eggs per individual or higher total number of ovipositing females. For how long the positive effects of $\mathrm{N}$ addition on the population dynamics of the heather beetle may last is still unsolved, as well as how vulnerable each life stage of the species might be to many other $\mathrm{N}$-driven changes in the host-plant (e.g., altered chemical defences: Hofland-Zijlstra and Berendse, 2009; Iason et al., 1993; increased susceptibility to frost and drought: Carroll et al., 1999; Meyer-Grünefeldt et al., 2015; Sheppard et al., 2008) and the heathland ecosystem (e.g., litter accumulation, reduced bryophytes and lichens: Carroll et al., 1999; Stevens et al., 2016).

Altogether, the findings that the larvae of the heather beetle are able to select the most N-rich Calluna shoots and reach high population numbers in response to the addition of $\mathrm{N}$ over prolonged time periods, support prior single observations made on local heathland areas across Europe, reporting that the most severe defoliation damage by the heather beetle is inflicted at the larval stage (e.g., Berdowski, 1993; Brunsting, 1982; Power et al., 1998b). Moreover, these findings also add up to the hypothesis that more frequent and severe population outbreaks are expected in heathland ecosystems under increased $\mathrm{N}$ deposition in the near future (Bobbink and Heil, 1993; Rosenburgh and Marrs, 2010).

For generalist predators to be effective in regulating populations of a pest species like the heather beetle, they should both display a strong food preference for the pest and take advantage of large accumulations of the pest's individuals (e.g., aphids: Monsrud and Toft, 1999; Toft, 2005). However, in our study, predatory ground beetles and harvestmen showed no consistent trend of response to the larvae of the heather beetle, and neither to the addition of $\mathrm{N}$ nor to the age of heathland vegetation. Ground beetles in particular were mostly active (i.e., abundant) at both N0 plots in the rejuvenated heathlands where very few larvae of the heather beetle occurred, and N5.6 plots in the mature ones where the highest larval abundances were recorded. Also, the enclosure field experiment confirmed the lack of aggregative numerical response of ground beetles to the increased availability of larvae at high $\mathrm{N}$-input plots. Polyphagous predators are generally expected to aggregate at high densities of high-quality or essential preys (i.e., preys with rich nutrient composition and no or weak toxins and deterrents resulting in maximal contribution to the fitness of the consumer), but not at high densities of low-quality or supplementary preys (Monsrud and Toft, 1999; Toft, 2005; Toft and Bilde, 2002). Both field surveys then suggest that the larvae of the heather beetle may be just one of a wide range of preys eaten by ground beetles and harvestmen, and may merely constitute supplementary food items that cannot alone sustain predator populations (Toft and Bilde, 2002). If this was true, we would expect that the availability of high-quality preys (e.g., flies and earthworms) in Calluna heathlands would determine the number of polyphagous predator individuals, and, thus, their potential role as population regulators of the heather beetle, as it has been described for other pest populations in agricultural systems (e.g., aphids: Monsrud and Toft, 1999; Toft, 2005; flies: Menalled et al., 1999; planthoppers: Sigsgaard et al., 2001).

The results of the cafeteria experiment also support the low value of the larvae of the heather beetle as food for generalist predators, since the ground beetle species tested, C. asturiensis, consumed a small number of larvae, both in total and per individual. Local field observational studies developed in the Netherlands over a 20-year period (den Boer, 1998) indicated that ground beetles may elude eating the larvae of the heather beetle because of their toxicity and low food value, and may instead switch to high-quality alternative preys when readily available. These long-term observations have indeed related high rates of consumption of heather beetle larvae with decreased ground beetle survival and fecundity, most likely denoting the low nutritional quality of the larvae (Chen et al., 2010; Toft and Bilde, 2002). Although further research is desirable to confirm these observations, it seems plausible that the noxious and toxic compounds (i.e., anthraquinones and dithranol) identified in larvae of the heather beetle as in many closely related species of the chrysomelid tribe Galerucini, subfamily Galerucinae (Hilker et al., 1992), serve as feeding deterrents against predators (e.g., ants: Hilker et al., 1992; birds: Hilker and Köpf, 1994) and may as well reduce predator performance. And yet, having developed an aversion to low-quality larvae of the heather beetle, ground beetles might still continue to consume them in the field, since the larvae (a) are easy to find due to their low activity and high density during population outbreaks (den Boer, 1998), (b) are easy of capture and handling thanks to their low escape ability, suitable size and softness (see Monsrud and Toft, 1999; Toft and Bilde, 2002), and (c) often constitute the only stable food source in Calluna heathlands to guarantee predator survival (den Boer, 1998).

Moreover, previous laboratory feeding experiments demonstrated that generalist predators like ground beetles are capable of foraging selectively on different-nutrient content preys to regulate their intake of specific macronutrients (mainly lipids and proteins), redress existing nutritional imbalances in these macronutrients, and maximise performance (Jensen et al., 2011, 2012; Mayntz et al., 2005; Wilder et al., 2010). In the cafeteria trials, the ground beetle species tested systematically avoided feeding on the larvae that were reared on N-treated Calluna plants, that is, the ones with improved nutritional composition (i.e., containing more $\mathrm{N}$ and protein and less lipid) (see Jensen et al., 2011; Mayntz and Toft, 2001; Wilder et al., 2010). This unexpected finding supports the idea that the test species prioritised eating the most lipid-rich larvae over protein-rich ones to rapidly build its lipid reserves and meet the energetic demands of dispersal, mating and reproduction before the end of summer (see Arrese and Soulages, 2010), in agreement with earlier studies (Jensen et al., 2012; Noreika et al., 2016; Raubenheimer et al., 2007; Wilder et al., 2010). Recent evidences in nutritional ecology suggest in fact that predators, including e.g., ground beetles and spiders, progressively ingest and assimilate fewer lipids at higher trophic levels, becoming increasingly lipid-limited and reliant on proteins as energy sources (Raubenheimer et al., 2009; Wilder et al., 2013); but they also indicate that over-consuming protein to gain limiting lipids results in reduced predator growth and reproduction (Jensen et al., 2012; Salomon et al., 2008), due to the high energetic costs of protein conversion into lipid storage (Jensen et al., 2012; Noreika et al., 2016). Whether ground beetles might be lipid- or protein-limited in heathland ecosystems may, however, de- 
pend on their natural nutritional state (see Mayntz et al., 2005; Noreika et al., 2016; Raubenheimer et al., 2007). This, together with prey availability, could determine their foraging behaviour (i.e., prey choice) and rate of predation on heather beetle larvae, especially when the larvae are grown on high-N Calluna plants and contain a high protein to lipid ratio (see e.g., Mayntz and Toft, 2001).

Taken together, (a) the relatively low number of ground beetles and harvestmen at high-N Calluna plots where the larvae of the heather beetle were very abundant, (b) the lack of aggregative numerical response of ground beetles to this accumulation of larvae, and (c) the low individual feeding rates of the ground beetle species tested, $C$. asturiensis, on the larvae of the heather beetle, particularly when raised on high-N food sources, imply that these two generalist predator groups are probably incapable to prevent and control the periodic population outbreaks of the heather beetle (see Toft, 2005; Toft and Bilde, 2002). As susceptibility of Calluna plants to secondary stress factors including the beetle's attacks will strengthen due to future increases in atmospheric $\mathrm{N}$ deposition (Phoenix et al., 2012; Sheppard et al., 2008; Stevens et al., 2016), more research is therefore needed to pursue the mechanisms that regulate the populations of the heather beetle to mitigate the damage.

\section{Acknowledgements}

We thank J. Calvo-Fernández, C. del Blanco, V. Fernández, R. Tárrega, and S. Turiel for collaboration. The Regional Administration (Junta de Castilla y León) granted authorisation for the field campaign (permit EP/LE/399/2013). The study was financed by the British Ecological Society (Research Grant 4901/5941).

\section{References}

Arrese, E.L., Soulages, J.L., 2010. Insect fat body: energy, metabolism, and regulation Annu. Rev. Entomol. 55, 207-225.

Behmer, S.T., 2009. Insect herbivore nutrient regulation. Annu. Rev. Entomol. 54, 165-187.

Berdowski, J.J.M., 1993. The effect of external stress and disturbance factors on Calluna-dominated heathland vegetation. In: Aerts, R., Heil, G.W. (Eds.), Heathlands Patterns and Processes in a Changing Environment. Kluwer Academic Publishers, the Netherlands, pp. 85-124.

Berdowski, J.J.M., Zeilinga, R., 1987. Transition from heathland to grassland: damaging effects of the heather beetle. J. Ecol. 75, 159-175.

Bobbink, R., Heil, G.W., 1993. Atmospheric deposition of sulphur and nitrogen in heathland ecosystems. In: Aerts, R., Heil, G.W. (Eds.), Heathlands: Patterns and Processes in a Changing Environment. Kluwer Academic Publishers, the Netherlands, pp. 25-50.

Bobbink, R., Hicks, K., Galloway, J., Spranger, T., Alkemade, R., Ashmore, M., Bustamante, M., Cinderby, S., Davidson, E., Dentener, F., Emmett, B., Erisman, J.-W., Fenn, M., Gilliam, F., Nordin, A., Pardo, L., de Vries, W., 2010. Global assessment of nitrogen deposition effects on terrestrial plant diversity: a synthesis. Ecol. Appl. 20, 30-59.

Brunsting, A.M.H., 1982. The influence of the dynamics of a population of herbivorous beetles on the development of vegetational patterns in a heathland system. In: Proceedings of the 5th International Symposium on Insect-plant Relationships, Wageningen. pp. 215-223.

Brunsting, A.M.H., Heil, G.W., 1985. The role of nutrients in the interactions between a herbivorous beetle and some competing plant species in heathlands. Oikos 44, 23-26.

Calvo, L., Alonso, I., Fernández, A.J., De Luis, E., 2005. Short-term study of effects of fertilisation and cutting treatments on the vegetation dynamics of mountain heathlands in Spain. Plant Ecol. 179, 181-191.

Calvo, L., Alonso, I., Marcos, E., De Luis, E., 2007. Effects of cutting and nitrogen deposition on biodiversity in Cantabrian heathlands. Appl. Veg. Sci. 10, 43-52.

Cameron, A.E., McHardy, J.W., Bennett, A.H., 1944. The Heather Beetle (Lochmaea suturalis). An Enquiry into its Biology and Control. British Field Sports Society, Petworth, Sussex.
Carroll, J.A., Caporn, S.J.M., Cawley, L., Read, D.J., Lee, J.A., 1999. The effect of increased deposition of atmospheric nitrogen on Calluna vulgaris in upland Britain. New Phytol. 141, 423-431.

Chen, Y., Olson, D.M., Ruberson, J.R., 2010. Effects of nitrogen fertilization on tritrophic interactions. Arthropod-Plant Interact. 4, 81-94.

Cuesta, D., 2015. Respuesta de las comunidades de artrópodos a las perturbaciones y a los cambios en la estructura de la vegetación en ecosistemas de matorral de la Cordillera Cantábrica. PhD Thesis University of Léon, Spain.

Cuesta, D., Taboada, A., Calvo, L., Salgado, J.M., 2006. A preliminary investigation of ground beetle (Coleoptera: Carabidae) assemblages and vegetation community structure in Calluna vulgaris heathlands in NW Spain. Entomol. Fenn. 17, 241-252.

Cuesta, D., Taboada, A., Calvo, L., Salgado, J.M., 2008. Short- and medium-term effects of experimental nitrogen fertilization on arthropods associated with Calluna vulgaris heathlands in north-west Spain. Environ. Pollut. 152, 394-402.

den Boer, P.J., 1998. The role of density-independent processes in the stabilization of insect populations. In: Dempster, J.P., McLean, I.F.G. (Eds.), Insect Populations. Kluwer Academic Publishers, Dordrecht, pp. 53-80.

Dentener, F., Drevet, J., Lamarque, J.F., Bey, I., Eickhout, B., Fiore, A.M., Hauglustaine, D., Horowitz, L.W., Krol, M., Kulshrestha, U.C., Lawrence, M., Galy-Lacaux, C., Rast, S., Shindell, D., Stevenson, D., Van Noije, T., Atherton, C., Bell, N., Bergman, D., Butler, T., Cofala, J., Collins, B., Doherty, R., Ellingsen, K., Galloway, J., Gauss, M., Montanaro, V., Müller, J.F., Pitari, G., Rodriguez, J., Sanderson, M., Solmon, F., Strahan, S., Schultz, M., Sudo, K., Szopa, S., Wild, O., 2006. Nitrogen and sulfur deposition on regional and global scales: a multimodel evaluation. Glob. Biogeochem. Cycles 20, GB4003. http://dx.doi.org/10.1029/ 2005GB002672.

Fagúndez, J., 2013. Heathlands confronting global change: drivers of biodiversity loss from past to future scenarios. Ann. Bot. 111, 151-172.

Fernandez, P., Hilker, M., 2007. Host plant location by Chrysomelidae. Basic Appl. Ecol. 8, 97-116.

Fox, J., Weisberg, S., 2011. An $\{\mathrm{R}\}$ Companion to Applied Regression, second ed Sage, Thousand Oaks CA. URL: http://socserv.socsci.mcmaster.ca/jfox/Books/ Companion.

Friedrich, U., von Oheimb, G., Dziedek, C., Kriebitzsch, W.-U., Selbmann, K., Härdtle, W., 2011. Mechanisms of purple moor-grass (Molinia caerulea) encroachment in dry heathland ecosystems with chronic nitrogen inputs. Environ. Pollut. $159,3553-3559$

Galloway, J.N., Dentener, F.J., Capone, D.G., Boyer, E.W., Howarth, R.W., Seitzinger, S.P., Asner, G.P., Cleveland, C.C., Green, P.A., Holland, E.A., Karl, D.M., Michaels, A.F., Porter, J.H., Townsend, A.R., Vörösmarty, C.J., 2004. Nitrogen cycles: past, present, and future. Biogeochemistry 70, 153-226.

Galloway, J.N., Townsend, A.R., Erisman, J.W., Bekunda, M., Cai, Z., Freney, J.R., Martinelli, L.A., Seitzinger, S.P., Sutton, M.A., 2008. Transformation of the nitrogen cycle: recent trends, questions and potential solutions. Science 320, 889-892.

García-Gómez, H., Garrido, J.L., Vivanco, M.G., Lassaletta, L., Rábago, I., Ávila, A., Tsyearo, S., Sánchez, G., González Ortiz, A., González-Fernández, I., Alonso, R., 2014. Nitrogen deposition in Spain: modelled patterns and threatened habitats within the Natura 2000 network. Sci. Total Environ. 485-486, 450-460.

Gimingham, C.H., 1972. Ecology of Heathlands. Chapman and Hall, London, UK

Gladbach, D.J., 2010. Effects of warming, drought and elevated $\mathrm{CO}_{2}$ on performance of an insect herbivore in heathland. PhD Thesis. In: Plant-insect Interactions in Changing Environments. Georg-August-Universität, Göttingen, Germany, pp. 51-67.

Haddad, N.M., Haarstad, J., Tilman, D., 2000. The effects of long-term nitrogen loading on grassland insect communities. Oecologia 124, 73-84.

Härdtle, W., von Oheimb, G., Gerke, A.-K., Niemeyer, M., Niemeyer, T., Assmann, T., Drees, C., Matern, A., Meyer, H., 2009. Shifts in N and P budgets of heathland ecosystems: effects of management and atmospheric inputs. Ecosystems $12,298-310$

Hartley, S.E., Gardner, S.M., Mitchell, R.J., 2003. Indirect effects of grazing and nutrient addition on the hemipteran community of heather moorlands. J. Appl. Ecol. 40, 793-803.

Hilker, M., Eschbach, U., Dettner, K., 1992. Occurrence of anthraquinones in eggs and larvae of several Galerucinae (Coleoptera: Chrysomelidae). Naturwissenschaften 79, 271-274.

Hilker, M., Köpf, A., 1994. Evaluation of the palatability of chrysomelid larvae containing anthraquinones to birds. Oecologia 100, 421-429.

Hillyard, P.D., Sankey, J.H.P., 1989. Harvestmen. Keys and Notes for the Identification of the Species. Synopses of the British Fauna (New Series). The Linnean Society of London. EJ Brill, Leiden, New York, Copenhagen, Cologne. 
Hofland-Zijlstra, J.D., Berendse, F., 2009. The effect of nutrient supply and light intensity on tannins and mycorrhizal colonisation in Dutch heathland ecosystems. Plant Ecol. 201, 661-675.

Iason, G.R., Hartley, S.E., Duncan, A.J., 1993. Chemical composition of Calluna vulgaris (Ericaceae): do responses to fertilizer vary with phenological stage? Biochem. Syst. Ecol. 21, 315-321.

Ikonen, A., 2002. Preferences of six leaf beetle species among qualitatively different leaf age classes of three Salicaceous host species. Chemoecology 12, 23-28.

Jeannel, R., 1941-1942. Coléoptères Carabiques. Faune de France. vols. 39 and 40. Lechevalier, Paris

Jensen, K., Mayntz, D., Toft, S., Clissold, F.J., Hunt, J., Raubenheimer, D., Simpson, S.J., 2012. Optimal foraging for specific nutrients in predatory beetles. Proc. R. Soc. B 279, 2212-2218.

Jensen, K., Mayntz, D., Toft, S., Raubenheimer, D., Simpson, S.J., 2011. Nutrient regulation in a predator, the wolf spider Pardosa prativaga. Anim. Behav. 81, 993-999.

Jones, A.G., Power, S.A., 2012. Field-scale evaluation of effects of nitrogen deposition on the functioning of heathland ecosystems. J. Ecol. 100, 331-342.

Jones, A.G., Power, S.A., 2015. Functional relationships with $\mathrm{N}$ deposition differ according to stand maturity in Calluna-dominated heathland. Ambio 44, 131-141.

Kerslake, J.E., Woodin, S.J., Hartley, S.E., 1998. Effects of carbon dioxide and nitrogen enrichment on a plant-insect interaction: the quality of Calluna vulgaris as a host for Operophtera brumata. New Phytol. 140, 43-53.

Krupa, S.V., 2003. Effects of atmospheric ammonia $\left(\mathrm{NH}_{3}\right)$ on terrestrial vegetation: a review. Environ. Pollut. 124, 179-221.

Lindroth, C.H., 1974. Handbooks for the Identification of British Insects. Royal Entomological Society, London, Coleoptera, Carabidae.

Mayntz, D., Raubenheimer, D., Salomon, M., Toft, S., Simpson, S.J., 2005. Nutrient-specific foraging in invertebrate predators. Science 307, 111-113.

Mayntz, D., Toft, S., 2001. Nutrient composition of the prey's diet affects growth and survivorship of a generalist predator. Oecologia 127, 207-213.

Menalled, F.D., Lee, J.C., Landis, D.A., 1999. Manipulating carabid beetle abundance alters prey removal rates in corn fields. BioControl 43, 441-456.

Meyer-Grünefeldt, M., Calvo, L., Marcos, E., von Oheimb, G., Härdtle, W., 2015. Impacts of drought and nitrogen addition on Calluna-heathlands differ with plant life-history stage. J. Ecol. 103, 1141-1152.

Monsrud, C., Toft, S., 1999. The aggregative numerical response of polyphagous predators to aphids in cereal fields: attraction to what?. Ann. Appl. Biol. 134, 265-270.

Nakazawa, M., 2014. fmsb: Functions for Medical Statistics Book with Some Demographic Data. R package version 0.5.1. URL: http://CRAN.R-project.org/ package $=$ fmsb.

Noreika, N., Madsen, N.E.L., Jensen, K., Toft, S., 2016. Balancing of lipid, protein, and carbohydrate intake in a predatory beetle following hibernation, and consequences for lipid restoration. J. Insect Physiol. 88, 1-9.

Ochoa-Hueso, R., Allen, E.B., Branquinho, C., Cruz, C., Dias, T., Fenn, M.E., Manrique, E., Pérez-Corona, M.E., Sheppard, L.J., Stock, W.D., 2011. Nitrogen deposition effects on Mediterranean-type ecosystems: an ecological assessment. Environ. Pollut. 159, 2265-2279.

Peñuelas, J., Gordon, C., Llorens, L., Nielsen, T., Tietema, A., Beier, C., Bruna, P., Emmett, B., Estiarte, M., Gorissen, A., 2004. Nonintrusive field experiments show different plant responses to warming and drought among sites, seasons, and species in a north-south European gradient. Ecosystems 7, 598-612.

Phoenix, G.K., Emmett, B.A., Britton, A.J., Caporn, S.J.M., Dise, N.B., Helliwell, R., Jones, L., Leake, J.R., Leith, I.D., Sheppard, L.J., Sowerby, A., Pilkington, M.G., Rowe, E.C., Ashmore, M.R., Power, S.A., 2012. Impacts of atmospheric nitrogen deposition: responses of multiple plant and soil parameters across contrasting ecosystems in long-term field experiments. Glob. Change Biol. 18, 1197-1215.

Pinder, A.C., Gillingham, P., Diaz, A., Stillman, R., 2015a. A Desk Review of the Ecology of Heather Beetle. Natural England Evidence Review, Number 008

Pinder, A.C., Gillingham, P., Diaz, A., Stillman, R., 2015b. Desk Review of Burning and Other Management Options for the Control for Heather Beetle. Natural England Evidence Review, Number 009.

Pinheiro, J., Bates, D., DebRoy, S., Sarkar, D., R Core Team, 2014. nlme: Linear and Nonlinear Mixed Effects Models. R package version 3.1-118. URL: http:/CRAN R-project.org/package $=$ nlme.

Pitcairn, C.E.R., Fowler, D., 1995. Deposition of fixed atmospheric nitrogen and foliar nitrogen content of bryophytes and Calluna vulgaris (L.) Hull. Environ. Pollut. 88, 193-205.

Power, S.A., Ashmore, M.R., Cousins, D.A., 1998a. Impacts and fate of experimentally enhanced nitrogen deposition on a British lowland heath. Environ. Pollut. $102,27-34$

Power, S.A., Ashmore, M.R., Cousins, D.A., Sheppard, L.J., 1998b. Effects of nitrogen addition on the stress sensitivity of Calluna vulgaris. New Phytol. 138, 663-673.
Power, S.A., Ashmore, M.R., Terry, A.C., Caporn, S.J.M., Pilkington, M.G., Wilson, D.B., Barker, C.G., Carroll, J.A., Cresswell, N., Green, E.R., Heil, G.W., 2004. Linking field experiments to long-term simulation of impacts of nitrogen deposition on heathlands and moorlands. Water, Air, Soil Pollut. Focus 4, 259-267.

Prieto, C.E., 2003. Primera actualización de la check-list de los Opiliones de la Península Ibérica e Islas Baleares. Rev. Ibérica Aracnol. 8, 125-141.

Prieto, C.E., 2008. Updating the Checklist of the Iberian opiliofauna: corrections, suppressions and additions. Rev. Ibérica Aracnol. 16, 49-65.

R Core Team, 2014. R: a Language and Environment for Statistical Computing. R Foundation for Statistical Computing, Vienna, Austria. URL: http://www. R-project.org/.

Raubenheimer, D., Mayntz, D., Simpson, S.J., Toft, S., 2007. Nutrient-specific compensation following diapause in a predator: implications for intraguild predation. Ecology 88, 2598-2608.

Raubenheimer, D., Simpson, S.J., Mayntz, D., 2009. Nutrition, ecology and nutritional ecology: toward an integrated framework. Funct. Ecol. 23, 4-16.

Rosenburgh, A., Marrs, R., 2010. The Heather Beetle: a Review (Report to the Heather Trust).

Sala, O.E., Chapin, F.S., Armesto, J.J., Berlow, E., Bloomfield, J., Dirzo, R., Huber-Sanwald, E., Huenneke, L.F., Jackson, R.B., Kinzig, A., Leemans, R., Lodge, D.M., Mooney, H.A., Oesterheld, M., Poff, N.L., Sykes, M.T., Walker, B.H., Walker, M., Wall, D.H., 2010. Global biodiversity scenarios for the year 2010. Science 287, 1770-1774.

Salomon, M., Mayntz, D., Lubin, Y., 2008. Colony nutrition skews reproduction in a social spider. Behav. Ecol. 19, 605-611.

Sánchez-Cuenca, D., 2012. Estudio taxonómico de las especies ibéricas del género Odiellus (Arachnida: Opiliones: Phalangidae). Bachelor's Thesis University of the Basque Country, Spain.

Scandrett, E., Gimingham, C.H., 1991. The effect of heather beetle Lochmaea suturalis on vegetation in a wet heath in NE Scotland. Holarct. Ecol. 14, 24-30.

Scherber, C., Gladbach, D.J., Stevnbak, K., Karsten, R.J., Schmidt, I.K., Michelsen, A., Albert, K.R., Larsen, K.S., Mikkelsen, T.N., Beier, C., Christensen, S., 2013. Multi-factor climate change effects on insect herbivore performance. Ecol. Evol. 3, 1449-1460.

Serrano, J., 2003. Catálogo de los Carabidae (Coleoptera) de la Península Ibérica. Monografías de la Sociedad Entomológica Aragonesa. vol. 9. Spain, Zaragoza.

Sheppard, L.J., Leith, I.D., Crossley, A., Van Dijk, N., Fowler, D., Sutton, M.A., Woods, C., 2008. Stress responses of Calluna vulgaris to reduced and oxidised N applied under 'real world conditions'. Environ. Pollut. 154, 404-413.

Sigsgaard, L., Toft, S., Villareal, S., 2001. Diet-dependent fecundity of the spiders Atypena formosana and Pardosa pseudoannulata, predators in irrigated rice. Agric. For. Entomol. 3, 285-295.

Southon, G.E., Field, C., Caporn, S.J.M., Britton, A.J., Power, S.A., 2013. Nitrogen deposition reduces plant diversity and alters ecosystem functioning: field-scale evidence from a nationwide survey of UK heathlands. PLoS One 8 (4), e59031. http: //dx.doi.org/10.1371/journal.pone.0059031.

Southon, G.E., Green, E.R., Jones, A.G., Barker, C.G., Power, S.A., 2012. Long-term nitrogen additions increase likelihood of climate stress and affect recovery from wildfire in a lowland heath. Glob. Change Biol. 18, 2824-2837.

Staley, J.R., 2000. Aspects of the Population Dynamics of Lochmaea suturalis Thomson., (Coleoptera: Chrysomelidae; Sub-family: Galerucinae), the Heather Beetle: a Combined Laboratory and Modelling Approach. PhD Thesis Newcastle University, UK.

Stevens, C.J., Payne, R.J., Kimberley, A., Smart, S.M., 2016. How will the semi-natural vegetation of the UK have changed by 2030 given likely changes in nitrogen deposition?. Environ. Pollut. 208, 879-889.

Taboada, A., Pérez-Aguirre, C., Assmann, T., 2012. A new method for collecting agile tiger beetles by live pitfall trapping. Entomologia Exp. Appl. 145, 82-87.

Throop, H.L., Lerdau, M.T., 2004. Effects of nitrogen deposition on insect herbivory: implications for community and ecosystem processes. Ecosystems 7, 109-133.

Toft, S., 2005. The quality of aphids as food for generalist predators: implications for natural control of aphids. Eur. J. Entomol. 102, 371-383.

Toft, S., Bilde, T., 2002. Carabid diets and food value. In: Holland, J.M. (Ed.), The Agroecology of Carabid Beetles. Intercept, Andover, pp. 81-110.

Uren, S.C., Ainsworth, N., Power, S.A., Cousins, D.A., Huxedrup, L.M., Ashmore, M.R., 1997. Long-term effects of ammonium sulphate on Calluna vulgaris. J. Appl. Ecol. 34, 208-216.

Venables, W.N., Ripley, B.D., 2002. Modern Applied Statistics with S, fourth ed Springer, New York.

von Melber, A., Heimbach, U., 1984. Outbreaks of the heather beetle Lochmaea suturalis (Thomson) (Col., Chrysomelidae) in Northwest-German Calluna heathlands during this century. Anzeiger für Schädlingskunde, Pflanzenschutz, Umweltschutz 57, 87-89. 
von Oheimb, G., Power, S.A., Falk, K., Friedrich, U., Mohamed, A., Krug, A., Boschatzke, N., Härdtle, W., 2010. N: P ratio and the nature of nutrient limitation in Calluna-dominated heathlands. Ecosystems 11,317-327.

Wilder, S.M., Mayntz, D., Toft, S., Rypstra, A.L., Pilati, A., Vanni, M.J., 2010. Intraspecific variation in prey quality: a comparison of nutrient presence in prey and nutrient extraction by predators. Oikos 119, 350-358.
Wilder, S.M., Norris, M., Lee, R.W., Raubenheimer, D., Simpson, S.J., 2013. Arthropod food webs become increasingly lipid-limited at higher trophic levels. Ecol. Lett. 16, 895-902. 